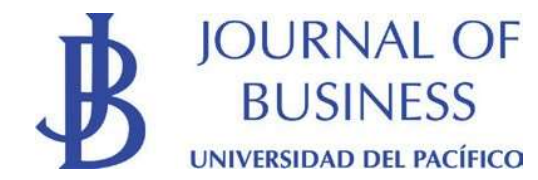

\section{Determining Factors of the Intention to Adopt Fintech Services by Micro and Small Business Owners from Chiclayo, Peru}

\author{
Janella Jhojani Merino Balcázar \\ Universidad Católica Santo Toribio de Mogrovejo \\ 71262154@usat.pe \\ Ángel Eduardo Llatas Rivas \\ Universidad Católica Santo Toribio de Mogrovejo \\ allatas@usat.edu.pe
}

\begin{abstract}
The objective of this research was to determine the factors that influence the intention to adopt fintech services by micro and small business owners from Chiclayo; for this purpose, an applied quantitative study was carried out in which the extended technology acceptance model proposed by Hu, Ding, Li, Chen and Yang (2019) was used for the analysis of nine variables related to the adoption of these technologies. The results reaffirmed that most of the constructs included in the conceptual model have great explanatory power regarding the adoption intention of fintech services, in that 11 of the 13 hypotheses were proven. Thus, it was demonstrated that business owners from Chiclayo use a new technology mainly under the influence of factors such as trust, brand image, and perceived utility, while also considering the potential risks to which they may be exposed; together, these considerations influence their attitude toward adopting fintech services. Finally, the analysis showed that government support and perceived ease of use have only a limited effect, while user innovativeness was the only factor that turned out to be non-significant in the intention to adopt this kind of services.
\end{abstract}

Keywords: fintech, adoption intention, micro and small enterprises, fintech services

\section{(c) $)$ EY}




\section{Factores determinantes de la intención de adopción de servicios Fintech por parte de micro y pequeños empresarios de Chiclayo, Perú}

\begin{tabular}{|c|}
\hline $\begin{array}{l}\text { Janella Jhojani Merino Balcázar } \\
\text { Universidad Católica Santo Toribio de Mogrovejo }\end{array}$ \\
\hline 71262154@usat.pe \\
\hline $\begin{array}{r}\text { Ángel Eduardo Llatas Rivas } \\
\text { Universidad Católica Santo Toribio de Mogrovejo } \\
\text { allatas@usat.edu.pe }\end{array}$ \\
\hline
\end{tabular}

\section{Resumen}

El objetivo de esta investigación fue determinar los factores que inciden en la intención de adoptar servicios fintech por parte de los micro y pequeños empresarios de Chiclayo; para ello se realizó un estudio cuantitativo aplicado en el que se utilizó el modelo de aceptación de tecnología extendida propuesto por Hu, Ding, Li, Chen y Yang (2019) para el análisis de nueve variables relacionadas con la adopción de estas tecnologías. Los resultados reafirmaron que la mayoría de los constructos incluidos en el modelo conceptual tienen un gran poder explicativo sobre la intención de adopción de los servicios fintech, ya que 11 de las 13 hipótesis fueron comprobadas. Así, se demostró que los empresarios de Chiclayo utilizan una nueva tecnología principalmente bajo la influencia de factores como la confianza, la imagen de marca y la utilidad percibida, considerando también los riesgos potenciales a los que pueden estar expuestos; juntas, estas consideraciones influyen en su actitud hacia la adopción de servicios fintech. Finalmente, el análisis mostró que el apoyo del gobierno y la facilidad de uso percibida tienen solo un efecto limitado, mientras que la innovación del usuario fue el único factor que resultó no significativo en la intención de adoptar este tipo de servicios. 


\section{Introduction}

It is widely known that micro and small enterprises (MSEs) constitute an important element in the economy of Latin American countries, whether due to their role as job creators $(51.2 \%$ of formal jobs are created by these companies) or to their predominance in the make-up of business (in which they represent $91 \%$ of the total). These organizations are a central pillar for guaranteeing not only economic growth but also social development and job creation in any nation (Dini \& Stumpo, 2018; International Labor Organization, 2019). However, this sector confronts numerous barriers that stand in the way of its development, among them informality and taxation systems (Ferraro \& Rojo, 2018), access to and costs of financing (Instituto Iberoamericano de Mercados de Valores IIMV, 2017), and the limited capacity of enterprises to adopt new technologies that allow them to reinvent their business model and adapt their management systems (Dini \& Stumpo, 2018). Of course, this reality has not bypassed Peru, where MSEs, despite driving the economy (Mathews, 2019), face challenges that range from access to financing and red tape(Cámara de Comercio de Lima, 2018), to innovation in business management (Ponce \& Zevallos, 2017).

Added to this problematic is the fortuitous impact of the COVID-19 pandemic, which has precipitated a drastic contraction in the global economy that most acutely affects developing countries (Banco Mundial, 2020). This occurrence, in turn, has shed light on the limited adoption of digital tools by Peruvian businesses; indeed, according to ComexPerú (2020), the country's MSEs exhibit serious lags in the implementation of such tools, which makes this one of the foremost challenges that must be tackled if these enterprises are to improve their competitiveness and adjust to the present circumstances. All this reveals the need for instruments that allow MSEs to pursue solutions that accord with their realities and contribute effectively to their market growth and development through more innovative management.

In parallel, recent years have witnessed the exponential growth of fintech startups that have arisen in response to latent market needs (Arner, Barberis \& Buckley, 2016). Peru is home to some 150 fintech companies that are currently transforming the industry (López, 2020), predominantly in the fields of payment methods and transfers, which account for market shares of $27.2 \%$ and $23.5 \%$, respectively (Ayllu Fintech \& Fintech Perú, 2019). But they are also present in other segments such as trade and markets, personal and corporate finance management, savings, insurance, and crowdfunding, among others (Finnovista, 2017). Thus, the outlook for the fintech industry is encouraging both for the entrepreneurs behind the organizations and their potential customers, in that these disruptive initiatives are assuming an increasingly prominent role in serving the specific needs of individuals and companies through innovative business models (Asociación de Bancos del Perú, 2019).

At this point, it is worth considering how MSEs might benefit from the adoption of fintech services. Arner, Barberis, Walker, Buckley, \& Zetzsche (2020) and IIMV (2017) pointed out that the foremost technological solutions from which MSEs stand to benefit include payment platforms, crowdlending, factoring, e-commerce solutions, and the implementation of digital payment. Moreover, at the present juncture, in which physical contact is to be minimized in the attempt to curb COVID-19 transmission, digital wallets and other forms of transaction that involve contactless payment have emerged as highly convenient alternatives (Arner et al., 2020), enabling transactions to be carried out quickly while adapting to the norms of social interaction established in Peru. Indeed, these solutions have become especially important within the MSE sector, in which innovation (Ponce \& Zevallos, 2017) and the adoption of technology (Maduku, Mpinganjira, \& Duh, 2016) are crucial for companies to achieve competitiveness and sustain their profit margins in the markets.

However, although these services are proving an excellent option for MSEs, factors such as cybercrime(Contreras, Diogo, Lopes, Herrero, \& Bueno, 2019), lack of state support (Hu et al., 2019), users' risk perception (Ryu, 2018), a dearth of public knowledge of such financial 
innovations, the underdeveloped credibility of the business models, and a paucity of regulation to facilitate the industry's development (Mendiola, 2020) can impede the development of fintechs for the benefit of Peruvians. To compound these challenges, only $51 \%$ of the Peruvian urban population is registered with the banking system, and of this group, just $52 \%$ use internet banking for their financial transactions (Ipsos Perú, 2020). This attests to the limited adoption of financial technologies and underlines the importance of analyzing the key factors that influence users' adoption of such innovations, given the need to capture the population segment that expresses reluctance to embrace digital technologies. And particular attention should be paid to the business sphere, in which these technologies can be pivotal to development.

\section{Literature review}

The term "fintech" is a portmanteau of "finance" and "technology" (Fortnum, Pollari, Mead, Hughes \& Speier, 2017) that has become especially popular in the financial sector (Gai, Qiu \& Sun, 2018) as a result of the dramatic transformation that technologies are effecting in the services that financial institutions offer (Ivashchenko et al., 2018). Indeed, fintech services emerge as innovative options that, by availing of the internet and automated data processing (Lee \& Shin, 2018) as well as emerging fields such as big data, artificial intelligence, loT, and cloud computing(Nakashima, 2018), seek to change the way in which financial products have traditionally been offered (Milian, Spinola \& De Carvalho, 2019).

To be sure, these innovative solutions have become particularly important for businesses, in that organizations such as MSEs require technological tools with which to modernize their processes and management models (ComexPerú, 2020). The Inter-American Development Bank (BID, 2018) has argued that because in Latin America there are a great many enterprises with only limited access to the traditional financial system--for reasons that range from business owners' lack of credit history to bureaucratic demands--fintech financing platforms represent a new option for entrepreneurs by offering an array of services that meet their needs. These include: crowdlending, an option in which the fintech platform acts as mediator by placing business owners in contact with potential lenders disposed to provide specific financing solutions in exchange for payment of a given interest rate (Maier, 2016); equity crowdfunding, a mechanism whereby companies will offer investors shares or commitments to provide benefits as consideration for contributions received (IIMV, 2017); reverse factoring, a solution that allows companies to pay their suppliers in advance by generating benefits for both parties (Hoder, Wagner, Sguerra \& Bertol, 2016); and factoring, an effective tool that contributes to increasing liquidity and working capital for small companies through the negotiation of invoices or collection rights (IIMV, 2017).

Other platforms that can be useful for the MSE sector are electronic payments, which optimize payment processes and create a financial trail for a company, thus making an indisputable contribution to improving credit rating by allowing financial institutions to verify its income flows through records of sales volumes (Hoder et al., 2016). The payment options provided by these platforms include POS terminals, contactless and digital payments, and QR code payments (Ivashchenko et al., 2018). These solutions, unlike traditional forms of payment, constitute personalized services adapted to the needs of customers, minimizing billing procedures through passwords or biometric authentication (Kang, 2018) and even helping to reduce the risk of theft associated with the use of cash (Urday, Morisaki, \& Fasanando, 2018). By the same token, convenience, speed, and flexibility are other characteristics for which these digital solutions stand out (Jünger \& Mietzner, 2020). They can also play an important role in facilitating pandemic-related social distancing by availing companies of mechanisms by which they can adapt to present circumstances and ensure their competitiveness in the region, all the while catalyzing the decades-long progression toward a cashless society (Arner et al., 2020). 
A category of fintech solution that fits this description is the e-commerce platform, which is particularly useful for MSEs that have entered this sector. For instance, payment aggregators (J. López, Langthaler, Fabian, \& Mayorga, 2017) and other online e-commerce payment platforms (Lavalleja, 2020), such as the fintech PagoEfectivo, allow customers to use a variety of payment methods to make online payments; this, whether through online or mobile banking, financial institutions, authorized agents or stores, users can make their payments in a quick and convenient manner. Another highly advantageous category for the MSE segment is business finance management, in which key services include electronic billing, digital accounting, financial management, business intelligence, and payment collection (BID, 2018).

However, although these business models can offer considerable benefits through a wide range of digital solutions, their usage hinges on certain aspects that can greatly affect adoption. The intention to adopt such innovations has been analyzed internationally from different perspectives (Ali, Muthaly, \& Dada, 2018; Contreras et al., 2019; Hu et al., 2019; Ivashchenko et al., 2018; Ryu, 2018; Stewart \& Jürjens, 2018). Some researchers have analyzed fintech adoption with a focus on aspects such as interest rates, processes, costs, amounts, and flexibility associated with the services (Rosavina, Rahadi, Kitri, Nuraeni, \& Mayangsari, 2019); while others have taken an entirely different approach, centering on factors like perceived utility and ease of use, government support, personal innovation, brand image, and user attitude (Hu et al., 2019); privacy, stigma, transactional distance, and social influence (Contreras et al., 2019); and trust, data security, value added, and user interface design $(\mathrm{H}$. Stewart \& Jürjens, 2018). Other studies have concentrated on exploring the multiple types of risk(Ryu, 2018; Savas, 2017) and benefits related to the use of this new type of digital platforms (Chang, Wong, Lee, \& Jeong, 2016).

All this illustrates the need to examine the perceptions and attitudes behind the behavior of Chiclayo business owners involved in the SME sector. But to this end it is necessary to apply a conceptual model that enables identification of the factors that prompt business owners to adopt these innovative solutions. In this regard, the technology acceptance model stands as the most practicable means by which to perform this analysis, as it explains and predicts the individual acceptance of information technology (IT) by users (Moon \& Kim, 2001). Thus, given the effectiveness of the TAM in explaining the disposition of individuals to adopt a given technology, and the fact it can be adapted to the characteristics of the analysis, this model has become one of the most used in the field of scientific research(Zhang, Lu \& Kizildag, 2018), having been employed through its extensions in various studies related to the acceptance of financial technology (Chong, Ooi, Lin \& Tan, 2010; Chuang et al., 2016; Contreras et al., 2019; Hu et al., 2019; Marakarkandy et al., 2017; Patel \& Patel, 2018).

Therefore, in this study we employ the model proposed by Hu et al. (2019) to determine the factors that influence the intention of owners of Chiclayo-based MSEs to adopt fintech services, since these authors drew on the TAM to develop a model adapted to the properties of the fintech sector, with its peculiarities such as privacy and security challenges, financial risks, storage of financial information, and so on. The authors, based on constructs from existing theories and models, added variables such as trust, brand image, perceived risk, government support, and user innovation--all of which are paramount to explaining the intention of individuals to adopt fintech technologies--to the factors included in the original TAM.

\section{Variables included in the extended TAM proposed by Hu et al. (2019)}

\section{Perceived usefulness}

In the TAM, perceived usefulness is a key factor due to its "relevance in the process of adopting a specific technology"(Patel \& Patel, 2018, p. 6). Davis (1989) defines perceived usefulness 
as the degree to which a person tends to use (or not) a specific application or system to the extent that it allows them to perform better in their activities, considering that this variable implies, in turn, that the use of the application or system provides a particular advantage to those who use it. Consequently, a system of high perceived utility is that in which the user has determined a positive use--performance relationship (Davis, 1989). Likewise, previous studies have demonstrated that this construct exercises a positive effect on users' behavioral intention(Y. Chang et al., 2016; Hu et al., 2019; Marakarkandy et al., 2017; Ryu, 2018; Venkatesh, Thong \& Xu, 2012); hence, its analysis is essential to determine the study subjects' intention to adopt. Along similar lines, Chang, et al. (2016) think that the usefulness of fintech services is related to its functional value, which covers factors such as convenience, performance, and cost advantages.

In this particular study, perceived usefulness is linked to the fact that users choose to adopt fintech services if they believe that these can be useful to their business processes and activities (Davis, 1989). In accordance with the aforementioned, it is assumed that the MSE owners' probability of adopting these services will increase if they perceive these financial innovations to be more useful and worthwhile than the traditional options. This gives rise to the following research hypothesis:

Hypothesis 1 (H1): The usefulness perceived by Chiclayo-based MSE owners has a positive impact on their attitude regarding the adoption of fintech services.

\section{Perceived ease of use}

Davis (1989) defined this factor as "the degree to which a person believes that using

a particular system would be free of effort." (p. 320). From this perspective, the author argued that perceived ease of use is based on the subject's direct experience with the objective system. However, it is worth noting that while the ease of use that users perceive can affect the degree of usefulness of a given service (Marakarkandy et al., 2017), this factor is of limited relevance at an initial stage of technology adoption since users will not yet have adapted to its usage (Hu et al., 2019). Moreover, on some occasions this variable can be influenced by certain inferential processes, since subjects can speculate when they predict the ease of use of a given system, taking into account their own skills and past experiences (Davis, 1986). Therefore, and in short, perceived ease of use is assumed to be the opposite of complexity (Yi, Fiedler, \& Park, 2006). In turn, although Venkatesh and Davis (2000) argue that this construct influences usage intention to a lesser extent than perceived usefulness--a premise that is supported by various authors (Chuang et al., 2016; Contreras et al., 2019)--many studies have demonstrated that perceived ease of use has a substantial impact on attitude toward using a given technology (Marakarkandy et al., 2017; Shankar \& Datta, 2018; Zhang et al., 2018).

Thus, taking the aforementioned into consideration, we propose the next hypothesis:

Hypothesis 2 (H2): Ease of use perceived by Chiclayo-based MSE owners positively affects their attitude in relation to intention to adopt fintech services.

Hypothesis $3(\mathrm{H} 3)$ : Ease of use perceived by MSE owners creates a positive effect on the perceived usefulness of fintech services.

\section{Attitude}

Ajzen (1989) described attitude as "an individual's disposition to respond favorably or unfavorably to an object [...]" (p.241); however, it is worth clarifying that this factor does not predispose a person to a particular behavior but rather it leads to a set of intentions to carry 
out a given action (Ajzen \& Fishbein, 1975). Traditionally, the TAM holds that there is a highly significant correlation between attitudes toward a particular technology and the intentions of subjects to adapt these systems (Davis, 1986). Thus, the results obtained by Chuang et al. (2016) and Hu et al. (2019) demonstrated that users' attitude contributes directly to their intention to adopt fintech services. These findings are complemented by those of Marakarkandy et al. (2017), which underline the importance of attitude as one of the main factors behind the adoption of a digital service. That said, this factor can be influenced by aspects such as perceived usefulness and ease of use (Tat, Suet, Chee, Aye \& Ling, 2018), trust (Marakarkandy et al., 2017), perceived risk (Savas, 2017), the brand of the service(Chuang et al., 2016) ,and government support (Hu et al., 2019). This leads us in turn to the next hypothesis:

Hypothesis $4(\mathrm{H} 4)$ : The attitude of the Chiclayo business owners toward the use of fintech services has a positive effect on the intention to adopt these technological innovations.

\section{Trust}

Over the years, trust has been one of the main factors analyzed when it comes to the adoption of technological innovations (Hu et al., 2019; Sánchez, Arroyo, Varon, \& Sánchez, 2018; Shankar \& Datta, 2018). In the fintech context in particular, this construct plays a crucial role given the nature of this type of innovations (Contreras et al., 2019). According to Stewart and Jürjens (2018), there are many factors that influence trust in the adoption of fintech services, most notably confidentiality, privacy, organizational reliability, and data and transaction security. Vance, Elie, and Straub (2008), established that an essential component in this factor is trust rooted in the institution, which can be defined as individual user conviction that the platform that they use for trading is secure. As such, its study in the present research is fundamental for two main reasons: first, it allows us to determine the ways in which trust affects the attitudes of MSE owners and their intention to adopt these new technologies; and second, it enables identification of the factors that could have a significant impact on the level of trust of potential users. Thus, given the relevance of this variable, we formulated the next research hypothesis:

Hypothesis 5 (H5): The trust of Chiclayo-based MSE owners in fintech services has a positive effect on their attitude toward the adoption of these technologies.

\section{Brand image}

Keller (1993) defines this variable as a consumer's perception of a specific brand based on the associations they hold in their memory, which give rise to brand meaning; this perception spans aspects that go beyond just the product or service that a company offers (Kavengi, 2013) to become an indispensable element in communicating organizational identity to current and potential users (Bravo, Montaner, \& Pina, 2012). Therefore, brand image can be defined as the backing given to products and services that allows companies and their users to build a solid relationship, improving customer recognition and satisfaction while generating trust (Hu et al., 2019). This construct is of considerable importance in the fintech industry given that factors such as reputation and brand credibility can, in the first instance, serve to overcome user distrust over the use of a new technology(Chuang et al., 2016); in this regard, the results of Hu et al. (2019) reveal that a good brand image can exert a positive influence on user trust and attitude regarding the use of fintech services.

Bravo et al. (2012) stressed the importance of the corporate brand, arguing that it is fundamental for positioning and developing the image of financial companies; thus, the possession by fintech entities of a positive brand image will help to strengthen the intentions of potential users with regard to the adoption of these services, given that consumers look to 
buy a major, well known and properly publicized brand (Derbaix, 1983). So, in light of the above, we propose:

Hypothesis $6(\mathbf{H 6})$ : The brand image of fintech entities has a positive impact on the attitude of MSE owners regarding the adoption of fintech services.

Hypothesis $7(\mathbf{H 7})$ : The brand image of fintech entities has a positive impact on the trust of MSE owners in fintech services.

\section{Perceived risk}

As emerging and unprecedented technologies, fintech services imply a series of broad-based risks that precipitate a degree of vulnerability among users (Ryu, 2018). Cox and Rich (1964) argued that this variable refers to the nature and the level of risk that a person perceives when they consider a specific decision. When it comes to fintechs, there are various factors--such as accidental divulgence of information, non-authorized access, hackers, etc.--that have a notable influence on consumers' sense of privacy, and may be perceived as risks by potential users (Contreras et al., 2019; Liao, Huang, \& Hsieh, 2016). In the era of information technology, perceived risk is considered by many studies as a decisive predictor in the adoption of innovative services (Kim, Mirusmonov, \& Lee, 2010; Liao et al., 2016; Savas, 2017) and online financial products(Kesharwani \& Singh, 2012; Marakarkandy et al., 2017), due to the major impact they can have on user trust (Hu et al., 2019) and attitude (Tat et al., 2018).

In the present study, this construct refers to the financial and privacy risk and that MSE owners warn of when they use fintech services. Financial risk can be defined as the net loss of money (Derbaix, 1983) that creates in users a feeling of insecurity with regard to the use of a particular technology(Forsythe, Liu, Shannon \& Gardner, 2006). Likewise, according to Ryu (2018), the risk of potential financial losses caused by the adoption of fintech services--usually associated with system malfunction, financial fraud, and additional transactional fees--have a negative influence on usage intention. In turn, privacy risk poses an inherent risk in the case of fintech services since these innovations make use of technologies such as Big Data, artificial intelligence, and cloud computing (Nakashima, 2018), and so by their nature they carry certain potential risks (Bettman, 1973) that are associated primarily with factors such as privacy of personal data and transaction security (Ryu, 2018).

As such, we formulated the following research hypotheses:

Hypothesis 8 (H8): Perceived risk negatively affects the attitude of Chiclayo-based MSE owners regarding the adoption of fintech services.

Hypothesis 9 (H9): The usefulness perceived by Chiclayo MSE owners has a negative impact on their trust regarding the use of fintech services.

\section{Government support}

Government support can be defined as the effort that the government makes to provide an adequate infrastructure and legal framework to positively influence the use of a given technology (Marakarkandy et al., 2017). This factor plays a crucial rule in the promotion and impetus of online services(Chong et al., 2010), lending credibility and viability to these new business models and assuring users that the service provider will operate in a well-run and organized manner (Tan \& Teo, 2000). Hence, government support presents itself as a key aspect in the creation of a facilitative environment (Marakarkandy et al., 2017) since the state, through its actions and regulations, raises the levels of trust in these forms of innovation(Rambocas \& Arjoon, 2012), thereby contributing to an increase in the likelihood of acceptance by possible adopters. This assumption is supported by $\mathrm{Hu}$ et al. (2019), who 
contended that by stepping up the promotion of fintech services and infrastructure investment (such as implementation of electricity and telecommunication networks), the government facilitates the adoption of these solutions by the population; this finding provides evidence, in turn, for the important leadership and operational role that the authorities can assume in the diffusion of innovation and technology use. This conditions the next research hypotheses:

Hypothesis 10 (H10): Government risk generates a positive effect on the attitude of Chiclayobased MSE owners regarding the adoption of fintech services.

Hypothesis 11 (H11): Government support has a positive impact on the trust of Chiclayobased MSE owners in fintech services.

\section{User innovation}

Hu et al. (2019) defined user innovation as the "degree of early adoption of a certain innovation by individuals" (p. 6). Accordingly, M. Chang, Cheung, and Lai (2005), proposed that innovation is the extent to which a person is receptive to new ideas, considering this factor to be a characteristic of each individual's personality. On the technological front, this variable can be understood as the tendency of a person to utilize a particular new technology, product, or information system (M. Chang et al., 2005; Tariq, 2007). Thus, because at present there is still a large number of people who are inexperienced with these services or platforms, individual innovation presents itself as a key element in the intention to adopt new technologies (Kim et al., 2010).

Hence, a highly innovative person will be distinguished primarily by their initiative in seeking out information about new ideas (Tariq, 2007) and for tolerating a high level of uncertainty, which leads this individual to be ,pre knowledgeable about a technology, to prove more receptive to said innovation (Leicht, Chtourou, \& Ben, 2018) and, in turn, to be more likely to adopt it. This is in keeping with previous publications (Contreras et al., 2019; Hu et al., 2019) that demonstrated that user innovation is intimately linked to the behavioral intention to adopt new technologies. However, this differs from Shankar and Datta (2018), who found that although personal innovation significantly influences perceived usefulness and ease of use, this variable does not have as direct impact on individual adoption intention. Thus, having analyzed the literature, we propose to test the following research hypotheses:

Hypothesis 12 (H12): Use innovation has a positive impact on the attitude of Chiclayo-based MSE owners regarding the adoption of fintech services.

Hypothesis 13 (H13): User innovation has a positive effect on the trust of Chiclayo-based MSE owners in relation to the use of fintech services.

\section{Adoption intention}

Ajzen and Fishbein (1975) define behavioral intention as the subjective probability that a person will carry out a particular form of behavior; thus, in this study, adoption intention is linked to the possibility that a MSE owner will adopt fintech services. The main goals of the questions corresponding to this variable were to determine the intention of the respondents to adopt these technological tools in the near future. It is worth noting that the intention to adopt a specific service is closely linked to its actual use; studies that support this premise include those by Moon and Kim (2001) and Marakarkandy et al. (2017), whose results revealed that, indeed, the actual use of a given technology is directly related to users' adoption intention. 


\section{Methodology}

The present research constitutes an applied causal-level and non-experimental study (Hernández, Fernández \& Baptista, 2014). As to the population, we established as our object of study the owners of micro- and small enterprises in various fields of business from the district of Chiclayo, who have used some type of fintech service for business purposes. This population is characterized by its unknown size and the lack of distinction between participants' sex, age, or education level. Thus, we opted for a nonprobability chain sampling which is the most convenient option for studying a population with these characteristics (Hernández et al., 2014). We thus established a non-probabilistic sample comprised of 101 business owners, whose demographic information can be consulted in Annex 02.

Data collection corresponded to a cross-cutting design, and our analysis employed a quantitative approach that allowed us to test the hypotheses formulated with regard to the variables used in the conceptual model. We used the survey technique, based on a structured online questionnaire composed of 30 items, which we prepared with the aid of the Google Forms application; we included a concise definition of "fintech services" in order to facilitate understanding of the questions. The items were divided into two sections. The first contained four descriptive questions that allowed us to ascertain general aspects about the respondents such as age, sex, type of company, and field of business. The second section included 26 assertive questions based on the conceptual model designed by $\mathrm{Hu}$ et al. (2019), which analyzed 9 constructs using the indicators shown in the "operationalization of variables" table (see Annex 01); we measured the items in this section by way of a Likert scale from 1 to 7 , in which $1=$ completely disagree $7=$ completely agree.

As to the procedure, the surveys were administered online and distributed among the research subjects from June to October 2020 through the Gmail service and the WhatsApp Messenger application. We statistically analyzed the data collected using the SmartPLS v.3.3.2. program, employing the structural equations model and the partial least squares method to test the hypotheses. Finally, it should be noted that the significance level of the path coefficients and the $R^{2}$ values were determined by way of the non-parametric bootstrapping procedure (see Annex 03).

\section{Results}

To evaluate the reflective measurement model we examined criteria such as external loads, internal consistency, and convergent validity (see Table 1). Hair, Risher, Sarstedt, and Ringle (2019) established that the factorial loads should be greater than 0.708; thus, as shown in Table 1, the external loads of all indicators varied between 0.772 and 0.964 , which indicates that they possess an acceptable level of reliability. In turn, we evaluated the internal consistency of the model using Cronbach's alpha and composite reliability. The critical value of the primary metric, according to Nunnally (1987) should be at least 0.80 ; thus, given that our analysis exhibited coefficients in excess of this value, it is confirmed that the measurement instrument used has a high level of explanatory reliability (Garson, 2013). However, although Cronbach's alpha is the most common measure of internal consistency, this procedure has the limitation of assuming that all indicators are equally reliable (Hair, Sarstedt, Ringle \& Mena, 2012); thus, composite reliability entails a more suitable measurement criteria for PLS-SEM (Hair et al., 2012), in which 0.70 is the minimum critical value that should be reached (Sarstedt, Ringle \& Hair, 2017). As such, because the analysis gives results that vary between 0.911 and 0.971 , it is confirmed that the model clearly exceeds the minimum expected level. 
Table 1

Reliability and validity of the model analyzed

\begin{tabular}{|c|c|c|c|c|c|c|}
\hline Constructs & $\begin{array}{l}\text { Key } \\
\text { name }\end{array}$ & Item & $\begin{array}{c}\text { External } \\
\text { loads } \\
>0.708\end{array}$ & $\begin{array}{c}\text { Cronbach' } \\
\text { s alpha } \\
\alpha>0.80\end{array}$ & $\begin{array}{l}\text { Composite } \\
\text { reliability }\end{array}$ & $\begin{array}{c}A V E^{\star}> \\
0.50\end{array}$ \\
\hline \multirow{3}{*}{ Attitude } & \multirow{3}{*}{ ATT } & ATT1 & 0.946 & \multirow{3}{*}{0.940} & \multirow{3}{*}{0.962} & \multirow{3}{*}{0.893} \\
\hline & & ATT2 & 0.932 & & & \\
\hline & & ATT3 & 0.956 & & & \\
\hline \multirow{3}{*}{$\begin{array}{l}\text { Government } \\
\text { support }\end{array}$} & \multirow{3}{*}{ GS } & GS1 & 0.900 & \multirow{3}{*}{0.879} & \multirow{3}{*}{0.911} & \multirow{3}{*}{0.775} \\
\hline & & GS2 & 0.772 & & & \\
\hline & & GS3 & 0.958 & & & \\
\hline \multirow{2}{*}{ Trust } & \multirow{2}{*}{ TRU } & CON1 & 0.950 & \multirow{2}{*}{0.891} & \multirow{2}{*}{0.948} & \multirow{2}{*}{0.902} \\
\hline & & CON2 & 0.949 & & & \\
\hline \multirow{3}{*}{$\begin{array}{l}\text { Perceived ease } \\
\text { of use }\end{array}$} & \multirow{3}{*}{ PEU } & PEU1 & 0.921 & \multirow{3}{*}{0.923} & \multirow{3}{*}{0.951} & \multirow{3}{*}{0.867} \\
\hline & & PEU2 & 0.942 & & & \\
\hline & & PEU3 & 0.930 & & & \\
\hline \multirow{3}{*}{ Brand image } & \multirow{3}{*}{$\mathrm{BI}$} & $\mathrm{BI} 1$ & 0.963 & \multirow{3}{*}{0.941} & \multirow{3}{*}{0.971} & \multirow{3}{*}{0.917} \\
\hline & & $\mathrm{BI} 2$ & 0.964 & & & \\
\hline & & $\mathrm{BI} 3$ & 0.945 & & & \\
\hline \multirow{2}{*}{ User innovation } & \multirow{2}{*}{ UI } & BI1 & 0.957 & \multirow{2}{*}{0.922} & \multirow{2}{*}{0.963} & \multirow{2}{*}{0.928} \\
\hline & & $\mathrm{BI} 2$ & 0.956 & & & \\
\hline \multirow{3}{*}{$\begin{array}{l}\text { Adoption } \\
\text { intention }\end{array}$} & \multirow{3}{*}{ INT } & INT1 & 0.938 & & & \\
\hline & & INT2 & 0.963 & 0.947 & 0.966 & 0.904 \\
\hline & & INT3 & 0.963 & & & \\
\hline & & RP1 & 0.940 & & & \\
\hline Perceived risk & PR & PR2 & 0.942 & 0.944 & 0.964 & 0.899 \\
\hline & & PR3 & 0.963 & & & \\
\hline & & PU1 & 0.936 & & & \\
\hline Perceived & PU & PU2 & 0.919 & 0.913 & 0966 & 0876 \\
\hline usefulness & I & PU3 & 0.952 & 0.943 & 0.900 & 0.810 \\
\hline & & UP4 & 0.937 & & & \\
\hline
\end{tabular}

Note: Average variance extracted.

Source: Compiled by authors based on the results of the SmartPLS v.3.3.2 software.

In addition, we examined convergent validity, which determines the extent to which the variables converge to explain the variance of their items (Hair et al., 2019); to this end, we examined average extracted variance (AVE). According to Fornell and Larcker (1981), for this metric to be acceptable it must have a value equal to or greater than 0.50 ; therefore, it can be concluded that the constructs in our model can explain more than $50 \%$ of the variance in the indicators, in that the results obtained fluctuated between 0.775 and 0.928 , in clear compliance with the critical level established.

In turn, when it comes to the analysis of the conceptual model (see Figure 1), it can be seen that the constructs $P U(\beta=0.140, t=3.639)$, PEU $(\beta=0.054, t=2.491)$, TRU $(\beta=0.285, t=$ 4.799), $\mathrm{BI}(\beta=0.225, \mathrm{t}=4.516), \mathrm{PR}(\beta=-0.315, \mathrm{t}=4.300)$, and $\mathrm{GS}(\beta=0.036, \mathrm{t}=3.182)$ had a positive impact on the variable ATT. Thus, given that the "t value" of these relations was greater than 1.96, the hypotheses $\mathrm{H} 1, \mathrm{H} 2, \mathrm{H} 5, \mathrm{H} 6, \mathrm{H} 8$, and $\mathrm{H} 10$ were proven (see Annex 03). 


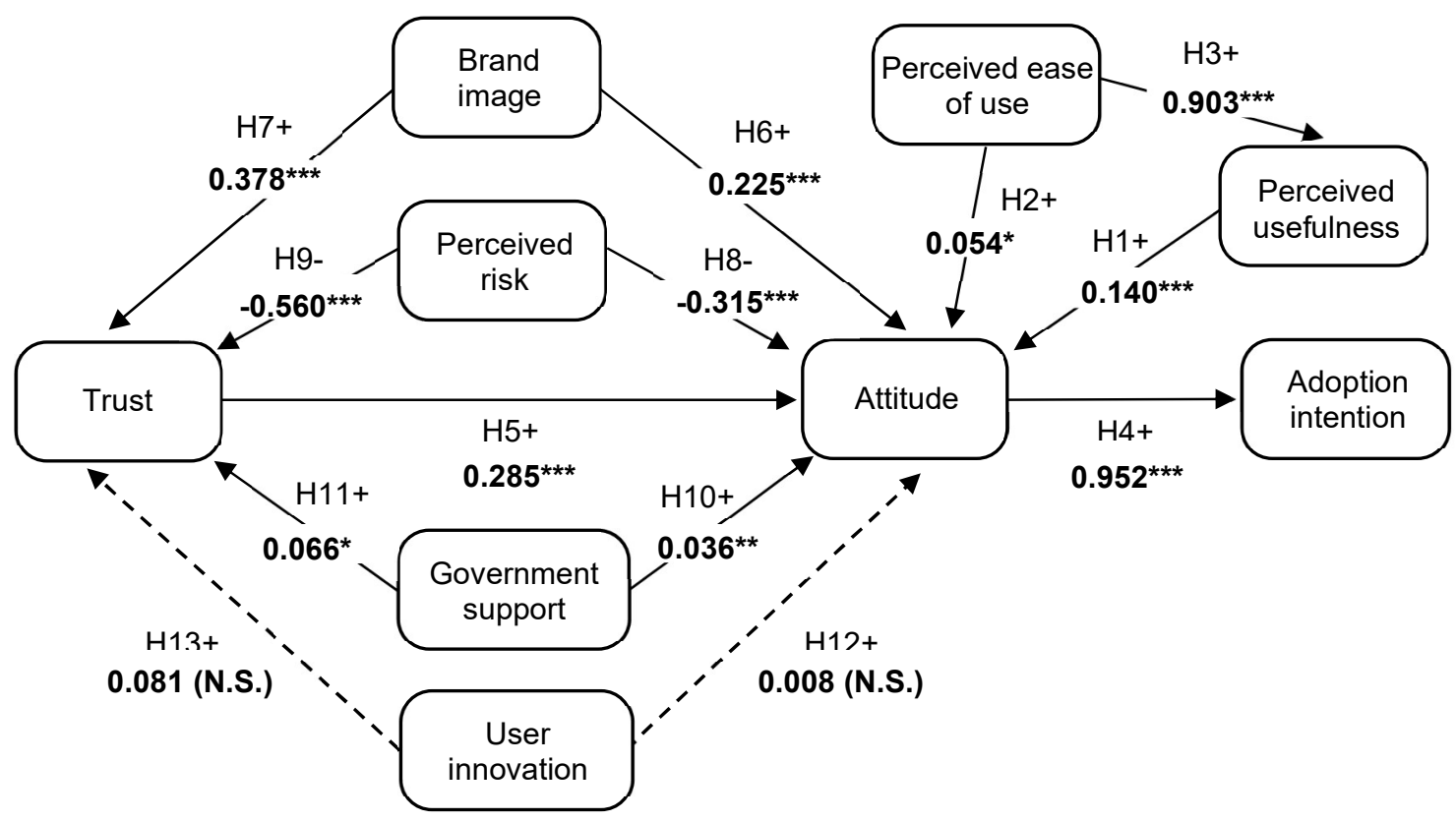

Figure 1. Analysis path of the conceptual model and hypothesis test

Note: ${ }^{*}, p<0.05 ;{ }^{* *}, p<0.01 ;{ }^{* * *}, p<0.001 ;$ N.S. $(--\rightarrow)$, non-significant.

Source: Compiled by authors based on the results of the SmartPLS v.3.3.2 software.

Likewise, the variables $B I(\beta=0.378, t=3.474), P R(\beta=-0.560, t=4.668)$ and $G S(\beta=0.066$, $t=2.171$ ) exerted a significant influence on the construct TRU, proving the hypotheses $H 7$, $\mathrm{H} 9$, and $\mathrm{H} 11$ with a significance level of less than $0.05(t>1.96)$. The results show that the variable PEA had a significant impact on the variable PU $(\beta=0.903, t=59.015)$, proving the hypothesis $\mathrm{H} 3$ at an error rate of less than $0.1 \%(t>3.1)$. On the other hand, the variable ATT $(\beta=0.952, t=113.660)$ had a significant effect on the construct INT, thus proving the hypothesis $\mathrm{H} 4$ at a confidence level of $99.9 \%$ ( $\mathrm{t}>3.1$ ). Finally, with regard to the construct $\mathrm{UI}$, the results demonstrated that there was no significant influence on the variables ATT $(\beta=$ $0.008, t=0.400)$ and TRU $(\beta=0.081, t=1.715)$; therefore, given that the " $p$ value" for both relationships was greater than the significance level (0.05), hypotheses $\mathrm{H} 12$ and $\mathrm{H} 13$ could not be proven; that is, there was insufficient evidence to conclude that the difference between the population average and the hypothetical average was statistically significant. It is worth noting that the model explained $90.70 \%$ of the variance of the dependent construct adoption intention) and, thus, in line with Sarstedt et al. (2017), this value indicates that its predictive ability is considerable.

\section{Discussion}

The abovementioned results demonstrate that the attitude of Chiclayo-based MSE owners had a major effect on their intention to adopt fintech services; and this variable, in turn, was influenced by factors such as brand image, trust, and the risk perceived by individuals.

In particular, brand image is one of the foremost determining factors in the intention of users to adopt fintech services, in that it positively influences both their attitude and their trust in this type of technological innovations. These findings are consistent with those presented in previous studies (Bravo et al., 2012; Hu et al., 2019), and primarily center around the fact that users tend to use financial services provided by entities that trade under a major and wellknown brand, and which are publicized successfully(Derbaix, 1983). Thus, it is vital that the institutions that offer fintech services are recognized by current and potential customers as 
serious businesses with a good reputation and the capability of offering high-quality products. Moreover, because brand image entails a consumer perception that goes far beyond just the services offered(Kavengi, 2013), the possession by these entities of a corporate brand that communicates their identity as credible organizations is decisive in positioning them as reliable companies within the business sector(K. Stewart, 1991).

Moreover, trust proved a key element in increasing the intention of MSE owners to adopt fintech services, showing that, through its influence on attitude, it has a notable impact on user intention (see Annex 04). The transcendence of this factor has been demonstrated over time (Contreras et al., 2019; Hu et al., 2019; Marakarkandy et al., 2017; H. Stewart \& Jürjens, 2018); indeed, it is considered one of the main determinants of the adoption of technological innovations. In the specific context of fintechs, this factor plays a key role since the use of these platforms, given their very nature, is related by users to situations of risk and uncertainty(Liao et al., 2016). In line with the results obtained, the trust of MSE owners is conditioned by aspects such as the brand image of the service provider and the risk the MSE owners perceive when they use these platforms--all of which are factors that allow these users to identify the level of security and reliability of fintech services. Indeed, because of the various vulnerabilities to which they could be exposed, much of the Peruvian population is reluctant to employ technologies of this type; so, even if they are aware of their efficiency, the fear that they could be exposed to cyberattacks, financial or data theft, and scams restricts their intention to adopt these financial innovations. This underlines the need for the fintech companies or financial institutions that offer these services to make efforts to bolster aspects such as confidentiality, data and transaction security, privacy, and organizational reliability to improve the trust of current and potential customers (H. Stewart \& Jürjens, 2018), as privacy and reliability are the most decisive factors in the adoption of these technologies by the market (Liao et al., 2016).

Meanwhile, perceived usefulness is a somewhat predictive factor, as it influences the attitude of users to adopting fintech services. This accords with the proposals of various researchers(Chang et al., 2016; Contreras et al., 2019; Hu et al., 2019; Marakarkandy et al., 2017; Moon \& Kim, 2001; Ryu, 2018), as it attests to the role perceived usefulness plays in the intention of users to adopt a given technology on account of the benefits or advantages that its use will provide them(Davis, 1989). Indeed, the intention of MSE owners to use fintech platforms stems to a certain degree from their functional value, which is associated with aspects such as convenience and performance (Chang et al., 2016), reduction in costs and bureaucratic processes (Contreras et al., 2019), and time and efficiency savings. Therefore, to the extent that these financial innovations cover the service-related needs of MSE owners and allow them to carry out their transactions more effectively than the traditional options (banks, municipal savings banks, payment agents, financiers, and so on), the adoption of these services will be positively affected.

Similarly, perceived ease of use has a highly significant influence on perceived usefulness and, in turn, affects the intention to adopt fintech services. The results show that this variable did not affect user attitudes to a great degree; indeed, although this result differs from that obtained in numerous publications (Contreras et al., 2019; Marakarkandy et al., 2017; Stewart \& Jürjens, 2018), it has been demonstrated that, at an initial stage of technology adoption, ease of use does not have a significant impact on adoption behavior(Hu et al., 2019) as users are not yet familiar with the system's functional characteristics or interface or else do not have the necessary grounding in how to interact with these platforms (Davis, 1989). However, the results of the present study provide evidence that this factor has an indirect impact on the adoption intention of MSE owners; this stems from perceived usefulness, which has an influence on users' attitude, thereby generating a moderately positive effect on adoption intention (see Annex 04).

On the other hand, the adoption of fintech services can be significantly affected by the risk that business owners perceive regarding their use, as this factor has a significant negative impact 
on user trust and attitude. In this way, it is demonstrated that the risk perceived by MSE owners plays a fundamental role in reducing the level of trust in these technological tools; thus, the greater the degree of perceived risk, the lower the level of trust and, in turn, the less favorable the attitude of individuals toward these services(Lee, 2009). This finding is consistent with the results obtained by various researchers (Marakarkandy et al., 2017; Hu et al.,2019; Ryu, 2018) and is closely related to aspects such as accidental divulgence and unauthorized access to accounts(Contreras et al., 2019), potential financial losses (Ryu, 2018) and cybercrimes, all of which can be perceived by users as potential risk factors. Thus, the institutions that provide fintech services ought to adopt measures to reduce perceived risk in order to strengthen trust in these platforms and increase the disposition of business owners to employ these services.

As to government support, the results demonstrate that this variable exerts a minimal degree of influence on the attitude and trust of Chiclayo-based MSE owners and that, as such, this is not a factor that determines intention to adopt fintech services to any great extent. Although these findings differ from those obtained in previous studies (Hu et al., 2019; Marakarkandy et al., 2017), they are consistent with the backdrop against which this research was carried out, given that, in Peru, there is not yet a legal framework in place that promotes the development of this industry (Mendiola, 2020). Added to this is the fact that parts of the country still lacks the necessary infrastructure--such as an adequate telecommunications or electricity network-that would allow the entire population to access to these services (Ministerio de Economía y Finanzas, 2019). Thus, even though the district of Chiclayo has adequate access to electricity and mobile networks, in some regions the situation is completely different and so overall user perception regarding government efforts to provide a high-quality infrastructure is relatively low. All this attests to the Peruvian government's lack of support for the use of fintech services, and highlights the need to work on policies that promote and lend credibility to the use of these technological innovations.

However, unlike previous publications (Contreras et al., 2019; Hu et al., 2019; Kim et al., 2010; Yi et al., 2006), the results yield insufficient evidence to conclude that user innovation influences the intention to adopt fintech services; this is partly because user innovation did not have a significant impact on user trust or attitude, and is borne out by the study of Shankar \& Datta (2018), in which it was determined that this variable does not have a major impact on the intention to adopt a digital financial solution. Therefore, it can be inferred that while the business owners consider themselves innovative individuals, this has no bearing on their predisposition to use these technologies. Indeed, even though innovation generally represents a key element in the intention to adopt new systems or technologies (Kim et al., 2010)--as it is related to a more receptive attitude and tolerance of a higher degree of uncertainty (Leicht et al., 2018)--this differs in large measure from the reality we have analyzed, in which the business owners expressed greater interest in aspects such as the credibility of institutions and the potential risk to which they could be exposed.

Finally, we identified that the attitude of users contributes directly to their intention to adopt a given technology; this finding is backed by previous studies in the financial sector, (Hu et al., 2019; Patel \& Patel, 2018) demonstrating that this factor leads to a set of intentions to perform a specific action (Ajzen \& Fishbein, 1975)--in this case, the adoption of fintech services. Indeed, the fact that users demonstrate a positive attitude toward these platforms is considered one of the main causes behind their ultimate use, since people's attitudes are crucial to their intentions and thus have a direct effect on their behavior (Marakarkandy et al., 2017).

\section{Conclusions}

The results obtained in this study illustrate that most of the constructs utilized in the conceptual model employed have considerable explanatory power regarding the intention to adopt fintech services, with 11 of the 13 hypotheses being proven. In this regard, the causal relationship between users' attitude and adoption intention proved the strongest, showing that factors such 
as trust, brand image, and perceived use have a positive and significant influence on the attitude of owners of micro and small enterprises. Moreover, perceived risk presents itself as a critical factor in the adoption of fintech services by part of this business segment, as it has a negative impact on the trust and attitude of users; thus, the greater the level of perceived risk, the more reluctant the business owners are to use these new financial solutions.

In turn, the findings show that government support has only a limited influence on the attitude and trust of Chiclayo-based MSE owners; however, this is because of the lack of promotion of the use of fintech services by the Peruvian government and underscores the need to work on policies that support and bolster the credibility and viability of using these technological solutions. In turn, user innovation proved not to be a significant factor in the adoption of fintech services, as the MSE owners demonstrated greater interest in aspects related to the credibility of the institutions and the risk of using these financial technologies.

Thus, it can be stated that Chiclayo-based MSE owners use a new technology or service primarily under the influence of factors such as trust, brand image, and perceived usefulness, considering in turn the potential risks they could be exposed to when they use them, which, together, influence their attitude toward adopting a specific technological innovation such as fintech services.

\section{Recommendations}

Lack of knowledge of fintech services among the Peruvian population, particularly the business sector, underlines the need to implement strategies to foster an increase in their usage. Indeed, the findings presented provide user information about the various factors that contribute, directly or indirectly, to the adoption of these services by Chiclayo-based business owners pertaining to the MSE sector. These inputs can serve as a basis for the execution of different promotional actions or campaigns by the institutions that provide these services, as doing so without prior analysis of aspects related to consumer behavior can prevent them from achieving their expected results in their target segments.

Thus, we recommend that the design of website or app interfaces through which fintech services are accessed be user-friendly and understandable for all, because difficulties using these platforms is often an impediment for potential customers, who, failing to understand how they work, opt instead for the traditional channels present on the market.

Moreover, we suggest that both fintech providers and the government undertake financial education programs in order to provide worthwhile advice and information about the use of digital services, prioritizing communication about aspects such as ensuring that the website is correct and that apps are downloaded via reliable sources such as Play Store, App Store, or the company website. At the same time, these initiatives should stress the importance of not disclosing personal data (account numbers or passwords) through text messages or telephone calls. We also recommend that these platforms allow the conformation of transactions by text message and that notifications of payments or deposits are sent to the number or email address registered by the user.

Likewise, the institutions within the ecosystem are advised to work on an offering targeted specifically at the MPE sector, given that their service can be of notable benefit to this business segment. Indeed, managers and marketing professionals ought to pay special attention to the usefulness of these services to their users, prioritizing as part of their campaigns the benefits associated with usage such as time savings, efficiency, flexibility and convenience, while stressing the increasing uptake of digital services by Peruvian consumers.

In addition, it is vital that the companies that provide these digital solutions possess a solid corporate brand that communicates their identity as credible organizations, thereby allowing these providers to develop a brand image with which to position themselves as reliable and 
transparent market operators. To this end, all the attributes publicized need to be reflected in the service provided to consumers, as the marketing drive will be for nothing if the service does not meet customer expectations, which could have a negative impact on the adoption of these services.

Meanwhile, the Peruvian government must support this fledgling industry through the implementation of regulatory, web security, and consumer protection policies and laws that support and lend credibility to the use of these technological innovations. At the same time, it is recommendable that the state design promotional campaigns to inform the public and business owners--especially those in the MSE segment--about how these services can improve the efficiency of the services they provide, detailing the benefits and educating users about the security measures that they need to follow so as not to fall victim to cyberattacks or data theft. Another aspect that should be worked on is the implementation of the necessary infrastructure, as it is necessary for the entire population to be connected to high-quality electricity and telecommunications networks in order to use these services in an effective manner.

Finally, from an academic standpoint, we recommend that future studies take into account psychological variables and factors related to the business sphere to allow for a more concrete analysis of the process of adoption by this market segment. We also suggest a comparative study of micro and small business owners that identifies differences related to demographic aspects (such as age, sex, and education level) and the characteristics of their companies (such as time operating and field of business). This would be greatly beneficial for the formulation of more personalized marketing campaigns and for the development of services that better meet the needs to this category of consumers.

\section{References}

Ajzen, I. (1989). Attitude Structure and Behavior. In A. Pratkanis, S. Breckler \& A. Greenwald (Eds.), Attitude structure and function (pp. 241-274). New Jersey: Lawrence Erlbaum.

Ajzen, I. \& Fishbein, M. (1975). Belief, Attitude, Intention, and Behavior: An Introduction to Theory and Research. Massachusetts: Addison-Wesley.

Ali, W., Muthaly, S. \& Dada, M. (2018). Adoption of Shariah compliant peer-to-business financing platforms by SMEs: A conceptual strategic framework for fintechs in Bahrain. International Journal of Innovative Technology and Exploring Engineering, 8(2), 407-412. Retrieved from content/uploads/papers/v8i2s2/ES2128017519.pdf https://www.ijitee.org/wp-

Arner, D. W., Barberis, J. \& Buckley, R. P. (2016). The Evolution of Fintech: A New Post-Crisis Paradigm? Georgetown Journal of International Law, 47(4), 1345-1393. https://doi.org/10.2139/ssrn.2676553

Arner, D. W., Barberis, J. N., Walker, J., Buckley, R. P. \& Zetzsche, D. A. (2020). Digital Finance \& Crisis. University of Hong Kong Faculty of Law Research No. 2020/017. https://doi.org/10.2139/ssrn.3558889

Asociación de Bancos del Perú. (2019). Ecosistema Fintech sigue Creciendo en América Latina.

Retrieved

from

https://www.asbanc.com.pe/Publicaciones/ASBANC_SEMANAL_318.pdf

Ayllu Fintech \& Fintech Perú. (2019). Radiografía de la industria Fintech en Perú. Lima. Retrieved from https://www.ayllufintech.org/static/Fintech2018.pdf 
Banco Interamericano de Desarrollo. (2018). Fintech América Latina 2018: Crecimiento y Consolidación. Retrieved from https://bit.ly/2UzlgCE

Banco Mundial. (June 8, 2020). La COVID-19 (coronavirus) hunde a la economía mundial en la peor recesión desde la Segunda Guerra Mundial. Retrieved from https://bit.ly/35SKFJR

Bettman, J. R. (1973). Perceived Risk and Its Components: A Model and Empirical Test. Journal of Marketing Research, 10(2), 184-190. https://doi.org/10.2307/3149824

Bravo, R., Montaner, T. \& Pina, J. M. (2012). Corporate brand image of financial institutions: A consumer approach. Journal of Product \& Brand Management, 21(4), 232-245. https://doi.org/10.1108/10610421211246649

Cámara de Comercio de Lima. (diciembre, 2018). Urge aumentar la competitividad de Mypes. La Cámara, 46-48. Retrieved from https://bit.ly/3xXAEal

Chang, M. K., Cheung, W. \& Lai, V. S. (2005). Literature derived reference models for the adoption of online shopping. Information \& Management, 42(4), 543-559. https://doi.org/10.1016/j.im.2004.02.006

Chang, Y., Wong, S. F., Lee, H. \& Jeong, S. P. (2016). What motivates Chinese consumers to adopt FinTech services. Proceedings of the 18th Annual International Conference on Electronic Commerce: E-Commerce in Smart Connected World (ICEC '16). Association for Computing Machinery (40), 1-3. https://doi.org/10.1145/2971603.2971643

Chong, A. Y., Ooi, K. B., Lin, B. \& Tan, B. I. (2010). Online banking adoption: an empirical analysis. International Journal of Bank Marketing, 28(4), 267-287. https://doi.org/10.1108/02652321011054963

Chuang, L., Liu, C. \& Kao, H. (2016). The Adoption of Fintech Service: TAM perspective. International Journal of Management and Administrative Sciences, 3(7), 1-15. Retrieved from https://www.ijmas.org/3-7//JMAS-3601-2016.pdf

ComexPerú. (June 12, 2020). Las MYPE peruanas y la adopción de nuevas tecnologías. Retrieved from https://bit.ly/3zXijw5

Contreras, L. H., Diogo, G. T., Lopes, E. L., Herrero, E. \& Bueno, R. L. P. (2019). Propensity of contracting loans services from FinTech's in Brazil. International Journal of Bank Marketing, 37(5), 1190-1214. https://doi.org/10.1108/IJBM-07-2018-0174

Cox, D. F. \& Rich, S. U. (1964). Perceived Risk and Consumer Decision-Making: The Case of Telephone Shopping. Journal of Marketing Research, 1(4), 32. https://doi.org/10.2307/3150375

Davis, F. D. (1986). A Technology Acceptance Model for Empirically Testing New End-User Information Systems: Theory and Results (doctoral thesis). Massachusetts Institute of Technology, Massachusetts. Retrieved from http://hdl.handle.net/1721.1/15192

Davis, F. D. (1989). Perceived Usefulness, Perceived Ease of Use, and User Acceptance of Information Technology. MIS Quarterly, 13(3), 319-340. https://doi.org/10.2307/249008

Derbaix, C. (1983). Perceived risk and risk relievers: An empirical investigation. Journal of Economic Psychology, 3(1), 19-38. https://doi.org/10.1016/0167-4870(83)90056-9

Dini, M. \& Stumpo, G. (Coords.). (2018). Mipymes en América Latina: un frágil desempeño y nuevos desafíos para las políticas de fomento. Comisión Económica para América Latina y el Caribe (CEPAL). Retrieved from https://bit.ly/3h0plsA 
Ferraro, C. \& Rojo, S. (2018). Las MIPYMES en América Latina y el Caribe: Una agenda integrada para promover la productividad y la formalización. Organización Internacional del Trabajo. Retrieved from https://bit.ly/3x2wU7k

Finnovista. (November 5, 2017). 47 Startups Fintech impulsan la oferta de mejores servicios financieros en Perú. Retrieved from https://bit.ly/35V9iWt

Fornell, C. \& Larcker, D. F. (1981). Evaluating Structural Equation Models with Unobservable Variables and Measurement Error. Journal of Marketing Research, 18(1), 39-50. https://doi.org/10.1177/002224378101800104

Forsythe, S., Liu, C., Shannon, D. \& Gardner, L. C. (2006). Development of a scale to measure the perceived benefits and risks of online shopping. Journal of Interactive Marketing, 20(2), 55-75. https://doi.org/10.1002/dir.20061

Fortnum, D., Pollari, I., Mead, W., Hughes, B. \& Speier, A. (2017). The Pulse of Fintech Q1 2017: Global analysis of investment in fintech. KPMG. Retrieved from https://bit.ly/3x0nqJY

Gai, K., Qiu, M. \& Sun, X. (2018). A survey on FinTech. Journal of Network and Computer Applications, 103, 262-273. https://doi.org/10.1016/j.jnca.2017.10.011

Garson, G. D. (2013). Scales \& Measures. Asheboro: Statistical Associates Publishers.

Goodwin, N. C. (1987). Functionality and usability. Communications of the ACM, 30(3), 229233. https://doi.org/10.1145/214748.214758

Hair, J. F., Risher, J. J., Sarstedt, M. \& Ringle, C. M. (2019). When to use and how to report the results of PLS-SEM. European Business Review, 31(1), 2-24. https://doi.org/10.1108/EBR-11-2018-0203

Hair, J. F., Sarstedt, M., Ringle, C. M. \& Mena, J. A. (2012). An assessment of the use of partial least squares structural equation modeling in marketing research. Journal of the Academy of Marketing Science, 40(3), 414-433. https://doi.org/10.1007/s11747-011-0261-6

Hernández, R., Fernández, C. \& Baptista, M. del P. (2014). Metodología de la Investigación (6 $6^{\text {ta }}$ ed.). Mexico City: McGraw-Hill.

Hoder, F., Wagner, M., Sguerra, J. \& Bertol, G. (2016). La Revolución Fintech: Cómo las Innovaciones Digitales están Impulsando el Financiamiento para las Mipyme en América Latina y El Caribe. Retrieved from https://owy.mn/3jhJ1JO

Hu, Z., Ding, S., Li, S., Chen, L. \& Yang, S. (2019). Adoption Intention of Fintech Services for Bank Users: An Empirical Examination with an Extended Technology Acceptance Model. Symmetry, 11(3), 340. https://doi.org/10.3390/sym11030340

Instituto Iberoamericano de Mercados de Valores. (2017). La Financiación de las Micro, Pequeñas y Medianas Empresas a Través de los Mercados de Capitales en Iberoamérica. Retrieved from https://bit.ly/3jncRN8

Ipsos Perú. (2020). Bancarización del Peruano. Lima. Retrieved from https://bit.ly/3w3aG3T

Ivashchenko, A., Britchenko, I., Dyba, M., Polishchuk, Y., Sybirianska, Y. \& Vasylyshen, Y. (2018). Fintech platforms in SME's financing: EU experience and ways of their application in Ukraine. Investment Management and Financial Innovations, 15(3), 83-96. https://doi.org/10.21511/imfi.15(3).2018.07 
Jünger, M. \& Mietzner, M. (2020). Banking goes digital: The adoption of FinTech services by German households. Finance Research Letters, 34, 101260. https://doi.org/10.1016/j.frl.2019.08.008

Kang, J. (2018). Mobile payment in Fintech environment: trends, security challenges, and services. Human-Centric Computing and Information Sciences, 8(1), 32. https://doi.org/10.1186/s13673-018-0155-4

Kavengi, G. (2013). The Impact of Bank Brand Image on Customer Satisfaction and Loyalty: A Case of Kenya Commercial Bank. European Journal of Business and Management, 5(21), 35-40. Retrieved from https://bit.ly/3hIBbfK

Keller, K. L. (1993). Conceptualizing, Measuring, and Managing Customer-Based Brand Equity. Journal of Marketing, 57(1), 1-22. https://doi.org/10.2307/1252054

Kesharwani, A. \& Singh, S. (2012). The impact of trust and perceived risk on internet banking adoption in India: An extension of technology acceptance model. International Journal of Bank Marketing, 30(4), 303-322. https://doi.org/10.1108/02652321211236923

Kim, C., Mirusmonov, M. \& Lee, I. (2010). An empirical examination of factors influencing the intention to use mobile payment. Computers in Human Behavior, 26(3), 310-322. https://doi.org/10.1016/j.chb.2009.10.013

Lavalleja, M. (2020). Panorama de las fintech: Principales desafíos para el Uruguay (No. 48). Montevideo. Comisión Económica para América Latina y el Caribe (CEPAL). Retrieved from https://bit.ly/3dsBqUS

Lee, I. \& Shin, Y. J. (2018). Fintech: Ecosystem, business models, investment decisions, and challenges. Business Horizons, 61(1), 35-46. https://doi.org/10.1016/j.bushor.2017.09.003

Lee, M. C. (2009). Factors influencing the adoption of internet banking: An integration of TAM and TPB with perceived risk and perceived benefit. Electronic Commerce Research and Applications, 8(3), 130-141. https://doi.org/10.1016/j.elerap.2008.11.006

Leicht, T., Chtourou, A. \& Ben Youssef, K. (2018). Consumer innovativeness and intentioned autonomous car adoption. The Journal of High Technology Management Research, 29(1), 1-11. https://doi.org/10.1016/j.hitech.2018.04.001

Liao, C., Huang, Y. J. \& Hsieh, T. H. (2016). Factors Influencing Internet Banking Adoption. Social Behavior and Personality: An International Journal, 44(9), 1443-1455. https://doi.org/10.2224/sbp.2016.44.9.1443

López, E. (2020). La expansión de las Fintech en el Perú. La Cámara, (914), 10-12. Recuperado de https://bit.ly/2U6wVZv

López, J., Langthaler, J., Fabian, M. \& Mayorga, J. (2017). Una Perspectiva General de Fintech: Sus Beneficios y Riesgos. Asociación de Supervisores Bancarios de las Américas. Retrieved from https://bit.ly/2U7OJDA

Maduku, D. K., Mpinganjira, M. \& Duh, H. (2016). Understanding mobile marketing adoption intention by South African SMEs: A multi-perspective framework. International Journal of Information Management, 36(5), 711-723. https://doi.org/10.1016/j.ijinfomgt.2016.04.018

Maier, E. (2016). Supply and demand on crowdlending platforms: connecting small and medium-sized enterprise borrowers and consumer investors. Journal of Retailing and Consumer Services, 33(1), 143-153. https://doi.org/10.1016/j.jretconser.2016.08.004 
Marakarkandy, B., Yajnik, N. \& Dasgupta, C. (2017). Enabling internet banking adoption. Journal of Enterprise Information Management, 30(2), 263-294. https://doi.org/10.1108/JEIM-10-2015-0094

Mathews, J. C. (2019). El necesario apoyo para las Mype en el Perú. Negocios Internacionales, 23(260), 44-45. Retrieved from https://bit.ly/3johSFb

Mendiola, A. (2020). El fenómeno fintech y sus desafíos. Diario Oficial El Peruano. Retrieved from https://bit.ly/3x64GbT

Milian, E., Spinola, M. \& De Carvalho, M. (2019). Fintechs: A literature review and research agenda. Electronic Commerce Research and Applications, 34, article 100833. https://doi.org/10.1016/j.elerap.2019.100833

Ministerio de Economía y Finanzas. (2019). Plan Nacional de Infraestructura para la Competitividad. Retrieved from https://bit.ly/3A876sJ

Moon, J. W. \& Kim, Y. G. (2001). Extending the TAM for a World-Wide-Web context. Information \& Management, 38(4), 217-230. https://doi.org/10.1016/S03787206(00)00061-6

Nakashima, T. (2018). Creating credit by making use of mobility with FinTech and IoT. IATSS Research, 42(2), 61-66. https://doi.org/10.1016/j.iatssr.2018.06.001

Nunnally, J. (1987). Teoría psicométrica. Mexico City: McGraw-Hill.

Organización Internacional del Trabajo. (2019). Small matters: Global evidence on the contribution to employment by the self-employed, micro-enterprises and SMEs. Retrieved from https://bit.ly/374LRtU

Patel, K. J. \& Patel, H. J. (2018). Adoption of internet banking services in Gujarat. International Journal of Bank Marketing, 36(1), 147-169. https://doi.org/10.1108/IJBM-08-2016-0104

Ponce, F. \& Zevallos, E. (2017). La innovación en la micro y la pequeña empresa (MYPE): no solo factible, sino accesible. 360: Revista de Ciencias de La Gestión, (2), 46-68. https://doi.org/10.18800/360gestion.201702.003

Rambocas, M. \& Arjoon, S. (2012). Using Diffusion of Innovation Theory to Model Customer Loyalty for Internet Banking: A TT Millennial Perspective. International Journal of Business and Commerce, 1(8), 1-14. Retrieved from https://bit.ly/3dp3o3R

Rosavina, M., Rahadi, R. A., Kitri, M. L., Nuraeni, S. \& Mayangsari, L. (2019). P2P lending adoption by SMEs in Indonesia. Qualitative Research in Financial Markets, 11(2), 260279. https://doi.org/10.1108/QRFM-09-2018-0103

Ryu, H. S. (2018). What makes users willing or hesitant to use Fintech?: the moderating effect of user type. Industrial Management \& Data Systems, 118(3), 541-569. https://doi.org/10.1108/IMDS-07-2017-0325

Sánchez, J., Arroyo, F., Varon, A. \& Sánchez, J. (2018). E-banking in Colombia: factors favouring its acceptance, online trust and government support. International Journal of Bank Marketing, 36(1), 170-183. https://doi.org/10.1108/IJBM-10-2016-0145

Sarstedt, M., Ringle, C. \& Hair, J. (2017). Partial Least Squares Structural Equation Modeling. In C. Homburg, M. Klarmann \& A. Vomberg (Eds.), Handbook of Market Research (Vol. 21, pp. 1-40). https://doi.org/10.1007/978-3-319-05542-8_15-1 
Savas, S. (2017). Perceived Risk and Consumer Adoption of Service Innovations. Florida Atlantic University, Boca Raton. Retrieved from https://bit.ly/3dsRHJv

Shankar, A. \& Datta, B. (2018). Factors Affecting Mobile Payment Adoption Intention: An Indian Perspective. Global Business Review, 19(3), 72-89. https://doi.org/10.1177/0972150918757870

Stewart, H. \& Jürjens, J. (2018). Data security and consumer trust in FinTech innovation in Germany. Information \& Computer Security, 26(1), 109-128. https://doi.org/10.1108/ICS06-2017-0039

Stewart, K. (1991). Corporate identity: a strategic marketing issue. International Journal of Bank Marketing, 9(1), 32-39. https://doi.org/10.1108/02652329110140833

Tan, M. \& Teo, T. (2000). Factors Influencing the Adoption of Internet Banking. Journal of the Association for Information Systems, 1, 1-44. Retrieved from https://bit.ly/3hmulRt

Tariq, B. (2007). Exploring Factors Influencing the Adoption of Mobile Commerce. Journal of Internet Banking and Commerce, 12(3), 32-42. Retrieved from https://bit.ly/2U7RnJw

Tat, C., Suet, L., Chee, L., Aye, A. \& Ling, R. (2018). Preliminary Study on Consumer Attitude towards FinTech Products and Services in Malaysia. International Journal of Engineering \& Technology, 7(29), 166-169. https://doi.org/10.14419/ijet.v7i2.29.13310

Urday, S., Morisaki, A. \& Fasanando, A. (2018). Reducción del uso del dinero en efectivo en el Perú. Asociación de Bancos del Perú. Retrieved from https://bit.ly/2U9AMoE

Vance, A., Elie, C. \& Straub, D. W. (2008). Examining Trust in Information Technology Artifacts: The Effects of System Quality and Culture. Journal of Management Information Systems, 24(4), 73-100. https://doi.org/10.2753/MIS0742-1222240403

Venkatesh, V. \& Davis, F. (2000). A Theoretical Extension of the Technology Acceptance Model: Four Longitudinal Field Studies. Management Science, 46(2), 186-204. https://doi.org/10.1287/mnsc.46.2.186.11926

Venkatesh, V., Thong, J. \& Xu, X. (2012). Consumer Acceptance and Use of Information Technology: Extending the Unified Theory of Acceptance and Use of Technology. MIS Quarterly, 36(1), 157-178. https://doi.org/10.2307/41410412

Yi, M., Fiedler, K. \& Park, J. (2006). Understanding the Role of Individual Innovativeness in the Acceptance of IT-Based Innovations: Comparative Analyses of Models and Measures. Decision Sciences, 37(3), 393-426. https://doi.org/10.1111/j.1540-5414.2006.00132.x

Zhang, T., Lu, C. \& Kizildag, M. (2018). Banking "on-the-go": examining consumers' adoption of mobile banking services. International Journal of Quality and Service Sciences, 10(3), 279-295. https://doi.org/10.1108/lJQSS-07-2017-0067 


\section{Annex 01: Operationalization of variables}

\section{Table 2: Operationalization of variables}

\begin{tabular}{|c|c|}
\hline Variables & Indicators \\
\hline Dependent & I am prepared to continue using fintech services. \\
\hline \multirow{2}{*}{$\begin{array}{l}\text { Adoption } \\
\text { intention }\end{array}$} & I would like to use fintech services soon. \\
\hline & I could recommend fintech services to my family and friends. \\
\hline Independent & $\begin{array}{l}\text { Using fintech services can satisfy my service needs (loans, payments, money } \\
\text { transfers, financing, business management, etc.). }\end{array}$ \\
\hline \multirow{3}{*}{$\begin{array}{l}\text { Perceived } \\
\text { usefulness }\end{array}$} & $\begin{array}{l}\text { Fintech services allow me to save time (e.g., by not having to go to the bank to carry } \\
\text { out my transactions or processes). }\end{array}$ \\
\hline & Fintech services can improve the efficiency of the services I perform. \\
\hline & I think that fintech services can be useful to me. \\
\hline \multirow{3}{*}{$\begin{array}{l}\text { Perceived } \\
\text { ease of use }\end{array}$} & IT is easy to use fintech services. \\
\hline & $\begin{array}{l}\text { I think that the operational interface of fintech platforms is user-friendly and } \\
\text { understandable. }\end{array}$ \\
\hline & $\begin{array}{l}\text { It is easy to have the necessary equipment for all fintech services (cellphone or } \\
\text { computer, mobile or web application, WiFi, etc.). }\end{array}$ \\
\hline \multirow{3}{*}{ Attitude } & I think that using fintech services is a good idea. \\
\hline & Using fintech services is a pleasant experience. \\
\hline & I am interested in fintech services. \\
\hline \multirow{3}{*}{ Trust } & I think that fintech services can keep my personal information safe. \\
\hline & Overall, I think that fintech services can be trusted. \\
\hline & $\begin{array}{l}\text { In think that the banking institutions that provide fintech platforms can provide good } \\
\text { services and products. }\end{array}$ \\
\hline
\end{tabular}

Brand image I think that I prefer accepting the services provided by well-known banking institutions.

In think that the banking institutions that offer fintech services have a good reputation.

\begin{tabular}{|c|c|}
\hline \multirow[b]{2}{*}{ Perceived risk } & I think that I am exposed to financial theft when I use fintech services. \\
\hline & In think that personal privacy can be violated through the use of fintech services. \\
\hline & Overall, I think that fintech services are risky. \\
\hline \multirow{3}{*}{$\begin{array}{l}\text { Government } \\
\text { support }\end{array}$} & In think that the government supports and improves the use of fintech services. \\
\hline & $\begin{array}{l}\text { I think that the government has established lays and regulations that are favorable for } \\
\text { the use of fintech services. }\end{array}$ \\
\hline & $\begin{array}{l}\text { I think that the government is active in the creation of all kinds of infrastructure, such } \\
\text { as electricity and telecommunications networks, which play a positive role in the } \\
\text { promotion of fintech services. }\end{array}$ \\
\hline \multirow{2}{*}{$\begin{array}{c}\text { User } \\
\text { innovation }\end{array}$} & When I hear about a new product I look for a way to try it out. \\
\hline & muaran of fomily and frionda 1 on \\
\hline
\end{tabular}

Source: Adapted from Hu et al. (2019). 


\section{Annex 02: Demographic characteristics of the sample}

Table 3

Demographic characteristics

\begin{tabular}{cccc}
\hline Demographic & variable and category & Frequency & Percentage \\
\hline \multirow{2}{*}{ Sex } & Male & 58 & $57.43 \%$ \\
\cline { 2 - 4 } & Female & 43 & $42.57 \%$ \\
\hline \multirow{3}{*}{ Age } & $25-34$ years & 16 & $15.84 \%$ \\
\cline { 2 - 4 } & $35-44$ years & 23 & $22.77 \%$ \\
\cline { 2 - 4 } & $45-54$ years & 31 & $30.69 \%$ \\
\cline { 2 - 4 } & $55-64$ years & 29 & $28.71 \%$ \\
\cline { 2 - 4 } Company type & 65 years and older & 2 & $1.98 \%$ \\
\cline { 2 - 4 } & Microenterprise & 57 & $56.44 \%$ \\
\cline { 2 - 4 } Company field & Small enterprise & 44 & $43.56 \%$ \\
\cline { 2 - 4 } & Industrial & 21 & $20.79 \%$ \\
\cline { 2 - 4 } & Retail & 43 & $42.57 \%$ \\
\cline { 2 - 4 } & Services & 37 & $36.63 \%$
\end{tabular}

Source: Compiled by authors based on the results of the survey administered. 
Merino Balcázar, J.J. and Llatas Rivas, A.E. (2021) Determining Factors of the Intention to Adopt Fintech Services by Micro and Small Business Owners from Chiclayo, Peru Vol.13(2): 19-43

\section{Annex 03: Analysis of significance level}

Table 4

Analysis of significance level of the path coefficients

\begin{tabular}{|c|c|c|c|c|c|}
\hline Hypothesis & $\begin{array}{c}\text { Path coefficients } \\
(\beta)\end{array}$ & Bootstrapping & $T$ test & $P$ values & Sig. \\
\hline $\mathrm{H} 1: \mathrm{UP} \rightarrow \mathrm{ACT}$ & 0.140 & 0.136 & 3.639 & 0.000 & $* * * *$ \\
\hline $\begin{array}{l}\mathrm{H} 2: \quad \mathrm{FUP} \rightarrow \\
\mathrm{ACT}\end{array}$ & 0.054 & 0.055 & 2.491 & 0.013 & * \\
\hline H3: FUP $\rightarrow$ UP & 0.903 & 0.903 & 59.015 & 0.000 & $* * *$ \\
\hline $\begin{array}{l}\text { H4: ACT } \rightarrow \\
\text { INT }\end{array}$ & 0.952 & 0.952 & 113.660 & 0.000 & $* * *$ \\
\hline $\begin{array}{l}\mathrm{H} 5: \mathrm{CON} \rightarrow \\
\mathrm{ACT}\end{array}$ & 0.285 & 0.282 & 4.799 & 0.000 & $* * *$ \\
\hline H6: IM $\rightarrow$ ACT & 0.225 & 0.225 & 4.516 & 0.000 & $* * *$ \\
\hline $\mathrm{H} 7: \mathrm{BI} \rightarrow \mathrm{TRU}$ & 0.378 & 0.379 & 3.474 & 0.001 & $* * *$ \\
\hline H8: PR $\rightarrow$ ATT & -0.315 & -0.321 & 4.300 & 0.000 & $* * *$ \\
\hline H9: PR $\rightarrow$ TRU & -0.560 & -0.560 & 4.668 & 0.000 & $* * *$ \\
\hline $\begin{array}{l}\text { H10: GS } \rightarrow \\
\text { ATT }\end{array}$ & 0.036 & 0.036 & 3.182 & 0.001 & $* *$ \\
\hline $\begin{array}{l}\text { H11: GS } \rightarrow \\
\text { TRU }\end{array}$ & 0.066 & 0.066 & 2.171 & 0.030 & * \\
\hline $\mathrm{H} 12: \mathrm{UI} \rightarrow$ ATT & 0.008 & 0.008 & 0.400 & 0.689 & N.S. \\
\hline $\begin{array}{l}\text { H13: IU } \rightarrow \\
\text { TRU }\end{array}$ & 0.081 & 0.081 & 1.715 & 0.086 & N.S. \\
\hline
\end{tabular}

Note: Sig., significance; ${ }^{*}, p<0.05 ;{ }^{* *}, p<0.01 ;{ }^{* * *}, p<0.001$; N.S., non-significant. Source: Compiled by authors based on the results of the SmartPLS v.3.3.2 software. 


\section{Annex 04: Specific indirect effects}

Table 5

Specific indirect effects - Analysis of significance

\begin{tabular}{|c|c|c|c|c|c|}
\hline Indirect effects & Path coefficients $(\beta)$ & Bootstrapping & T test & $P$ values & Sig. \\
\hline $\mathrm{CON} \rightarrow \mathrm{ATT} \rightarrow \mathrm{INT}$ & 0.271 & 0.268 & 4.811 & 0.000 & $* * *$ \\
\hline $\mathrm{BI} \rightarrow \mathrm{ATT} \rightarrow \mathrm{INT}$ & 0.214 & 0.213 & 4.492 & 0.000 & $* * *$ \\
\hline $\mathrm{PU} \rightarrow \mathrm{ATT} \rightarrow \mathrm{INT}$ & 0.133 & 0.129 & 3.569 & 0.000 & $* * *$ \\
\hline $\mathrm{PEU} \rightarrow \mathrm{PU} \rightarrow \mathrm{ATT}$ & 0.126 & 0.123 & 3.553 & 0.000 & $* * *$ \\
\hline $\mathrm{PEU} \rightarrow \mathrm{PU} \rightarrow \mathrm{ATT} \rightarrow \mathrm{INT}$ & 0.120 & 0.117 & 3.538 & 0.000 & $* * *$ \\
\hline $\mathrm{BI} \rightarrow \mathrm{TRU} \rightarrow \mathrm{ATT}$ & 0.108 & 0.108 & 2.467 & 0.014 & * \\
\hline $\mathrm{BI} \rightarrow \mathrm{TRU} \rightarrow \mathrm{ATT} \rightarrow \mathrm{INT}$ & 0.103 & 0.103 & 2.460 & 0.014 & * \\
\hline $\mathrm{PEU} \rightarrow \mathrm{ATT} \rightarrow \mathrm{INT}$ & 0.051 & 0.053 & 2.533 & 0.011 & * \\
\hline $\mathrm{GS} \rightarrow \mathrm{ATT} \rightarrow \mathrm{INT}$ & 0.034 & 0.034 & 3.168 & 0.002 & ** \\
\hline $\mathrm{UI} \rightarrow \mathrm{TRU} \rightarrow \mathrm{ATT}$ & 0.023 & 0.024 & 1.492 & 0.136 & N.S. \\
\hline $\mathrm{UI} \rightarrow \mathrm{CTRU} \rightarrow \mathrm{ATT} \rightarrow \mathrm{INT}$ & 0.022 & 0.023 & 1.490 & 0.136 & N.S. \\
\hline $\mathrm{GS} \rightarrow \mathrm{TRU} \rightarrow \mathrm{ATT}$ & 0.019 & 0.018 & 2.097 & 0.036 & * \\
\hline $\mathrm{GS} \rightarrow \mathrm{TRU} \rightarrow \mathrm{ATT} \rightarrow \mathrm{INT}$ & 0.018 & 0.017 & 2.098 & 0.036 & * \\
\hline $\mathrm{UI} \rightarrow \mathrm{ATT} \rightarrow \mathrm{INT}$ & 0.008 & 0.007 & 0.401 & 0.688 & N.S. \\
\hline $\mathrm{PR} \rightarrow \mathrm{TRU} \rightarrow \mathrm{ATT} \rightarrow \mathrm{INT}$ & -0.152 & -0.148 & 4.241 & 0.000 & $* * *$ \\
\hline $\mathrm{PR} \rightarrow \mathrm{TRU} \rightarrow \mathrm{ATT}$ & -0.159 & -0.155 & 4.227 & 0.000 & $* * *$ \\
\hline $\mathrm{PR} \rightarrow \mathrm{ATT} \rightarrow \mathrm{INT}$ & -0.300 & -0.307 & 4.409 & 0.000 & $* * *$ \\
\hline
\end{tabular}

Note: Sig., significance; ${ }^{*}, p<0.05 ;{ }^{* *}, p<0.01 ;{ }^{* * *}, p<0.001$; N.S., non-significant. Source: Compiled by authors based on the results of the SmartPLS v.3.3.2 software. 